\title{
Easter Day
}

\section{A. G. Fulcher}

To cite this article: A. G. Fulcher (1896) Easter Day, Folklore, 7:1, 90-90, DOI:

10.1080/0015587X.1896.9720343

To link to this article: http://dx.doi.org/10.1080/0015587X.1896.9720343

曲 Published online: 14 Feb 2012.

Submit your article to this journal

Q View related articles $₫$ 


\section{Easter Day.}

An old woman (Mrs. Burton, of Colkirk, Norfolk) says her father used always to get up extra early to see the sun rise on Easter Sunday, for on that day it "dances as if in agony." She has been very accurate in other legends she has told me, but is unable to give any clue to the reason for the agony. Possibly some one may be able to explain it from a similarity of belief in other counties.

A. G. FuLCHER.

\section{First-FOOT.}

A ncighbour, a widow lady from Lancashire, arranged through a friend with my gardener to come as "First-foot" on Tucsday night, the 3tst December last, at ten minutes past twelve. He rang the bell, and the lady herself came to the door and enquired "Who's there?" The gardener answered, as instructed, "The Ncw' Ycar." She immediately opened the door, saying, "Walk in, New Year." Ile went inside, and said, "I wish a happy New Year to all in this house." Thereupon she took him into the drawing-room, where refreshments were laid out on the table for him, of which he partook, and was also rewarded with halfa-crown. She has becn accustomed to do this for many years, no doubt crer since she has lived in the ncighbourhood. The parish clerk (it was a country village) was always the "First-foot" until the present year; and in casting about on account of his illness for a new one, she was very emphatic that it must be a dark man, and not grey.

The gardener tells the that as a boy he frequently carned twelve or fourtecn shillings on a New Year's morning by going as "Firstfoot." It was not done at night, but early in the morning. The practice was to go in at one door, wish the inhabitants of the house a happy New Year, and then go out of the house by another door, if there was onc. He says he never heard of any preference in this part of the world for a dask or a light man.

E. SIDNEY HaRtLaNd.

Gloucester. 